\title{
Pemberian Imunisasi Hepatitis B pada Bayi Prematur
}

\author{
Ismalita
}

Hepatitis B (HB) merupakan salah satu penyakit yang menjadi masalah kesehatan masyarakat di dunia. Tidak kurang dari 2000 juta orang telah terinfeksi virus HB ini dan lebih dari 350 juta merupakan pengidap kronik, yang dalam kurun waktu 10-20 tahun dapat berkembang menjadi sirosis atau hepatoma. Infeksi pada anak kebanyakan bersifat asimtomatik atau sering dengan gejala sub-klinik. Hepatitis B dapat berkembang menjadi bentuk fulminan, dengan angka kematian yang tinggi. Penyakit ini membunuh 1 juta manusia setiap tahun. Pada saat ini sudah dikembangkan vaksin HB yang aman dan efektif untuk mencegah penyakit tersebut. Pada tulisan ini akan dibahas jadwal, dosis dan hal yang perlu diperhatikan pada pemberian imunisasi HB pada bayi prematur, termasuk bayi berat lahir rendah.

Kata kunci: hepatitis B, imunisasi, prematur, berat lahir rendah.

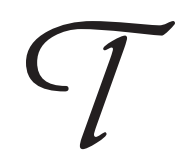

ujuan akhir (ultimate goal) imunisasi adalah mengeradikasi penyakit, dengan tujuan perantara (immediate goal) untuk mencegah penyakit baik secara individu maupun kelompok. ${ }^{1}$ Tujuan utama imunisasi hepatitis B (HB) ialah untuk mencegah terjadinya hepatitis kronik serta karier dan bukan untuk menyembuhkan hepatitis akut atau infeksi oleh virus $\mathrm{HB}$ (VHB). ${ }^{2}$ Prioritas pemberian imunisasi di setiap negara tergantung pada situasi epidemiologi penyakit di negara tersebut. Dengan diterimanya ide WHO mengenai Universal Child of Immunization (UCI), maka imunisasi di negara berkembang telah dirangkum dalam Expanded Program of Immunization (EPI), yang di Indonesia dikenal sebagai Pengembangan Program Imunisasi (PPI). ${ }^{1}$ Pada tahun 1991, EPI menetapkan target untuk menyertakan imunisasi HB dalam program nasional. Pada tahun 1992, World Health Assembly menyetujui menyertakan imunisasi HB ini dalam program nasional di semua negara dengan prevalensi pengidap $\mathrm{HBsAg} \geq 8 \%$, namun baru tahun 1997 program ini disetujui untuk dilaksanakan di semua negara. Saat ini kira-kira 100

\footnotetext{
Alamat korespondensi:

Dr. Ismalita

Bagian Ilmu Kesehatan Anak FK USU/RS HAM

Jalan Bunga Lau No. 17 Medan.

Telepon : (061) 8361721, Fax, : (061) 8361721
}

negara telah memasukkan imunisasi HB ke dalam program imunisasi nasional mereka. Sasaran WHO adalah penurunan insidens pengidap baru $\mathrm{HB}$ pada anak-anak tahun 2001 sebesar $80 \%{ }^{3}$

Indonesia adalah negara dengan angka prevalensi HB berkisar antara 5-20\%, termasuk negara dengan endemisitas sedang sampai tinggi, dengan transmisi vertikal $48 \%$. Oleh karena itu, strategi yang paling tepat untuk Indonesia ialah memberikan imunisasi HB pada bayi segera setelah lahir, ${ }^{2-5}$ kecuali pada keadaan khusus seperti bayi prematur, termasuk bayi berat lahir rendah. ${ }^{6,7}$ Sebaiknya imunisasi HB diberikan bersamaan dengan imunisasi BCG. ${ }^{1,6}$ Dosis dan jadwal imunisasi HB diberikan berdasarkan status HBsAg ibu. ${ }^{1,5,-11}$

\section{Jadwal imunisasi dan dosis imunisasi}

Pada dasarnya suatu jenis vaksin dibuat untuk diberikan kepada seseorang yang mempunyai respons imun yang baik dan memang perlu dilindungi terhadap penyakit tertentu. Faktor yang penting dan berpengaruh pada respons imunogenik adalah dosis antigen yang diberikan, umur bayi/anak, dan keadaan kompetensi imun resipien. Di samping hal tersebut, respons imunologi yang optimal harus seimbang dengan kebutuhan, sehingga tujuan imunisasi dapat dicapai. ${ }^{1}$

Tujuan penentuan jadwal imunisasi adalah untuk 
keseragaman dan mendapatkan respons imun yang teratur. ${ }^{1}$ Sebuah studi menunjukkan bahwa paling tidak 3,9\% ibu hamil merupakan pengidap hepatitis dengan risiko transmisi maternal kurang lebih sebesar 45\%. ${ }^{5}$ Dengan melihat faktor risiko dan cara penularan vertikal dari ibu ke anak, maka program imunisasi Departemen Kesehatan memprioritaskan imunisasi HB pada bayi segera setelah lahir dengan mengintegrasikannya ke dalam program imunisasi rutin yang telah ada. ${ }^{12}$ Untuk bayi-bayi yang dilahirkan di rumah sakit, imunisasi $\mathrm{HB}$ dosis pertama diberikan pada umur 0 bulan, dosis kedua diberikan pada umur 2 bulan dan dosis ketiga diberikan pada umur 7 bulan. Jadwal imunisasi HB bagi bayi yang datang di rumah sakit / posyandu adalah dosis pertama pada umur 3 bulan, dosis kedua pada umur 4 bulan, dan dosis ketiga diberikan pada umur 9 bulan. ${ }^{11,12}$

Pemberian imunisasi HB pada bayi berdasarkan status $\mathrm{HBsAg}$ ibu pada saat melahirkan, sebagai berikut: ${ }^{5,11}$

1. Bayi lahir dari ibu dengan status $\mathrm{HBs} A g$ yang tidak diketahui.

Diberikan vaksin rekombinan $(10 \mu \mathrm{g})$ secara intramuskular, dalam waktu 12 jam sejak lahir. Dosis ke dua diberikan pada umur 1-2 bulan dan dosis ke tiga pada umur 6 bulan. Apabila pada pemeriksaan selanjutnya diketahui $\mathrm{HbsAg}$ ibu positif, segera berikan $0,5 \mathrm{ml}$ imunoglobulin anti hepatitis (HBIG) (sebelum usia 1 minggu).

2. Bayi lahir dari ibu dengan $\mathrm{HBsAg}$ positif.

Dalam waktu 12 jam setelah lahir, secara bersamaan diberikan 0,5 ml HBIG dan vaksin rekombinan secara intramuskular di sisi tubuh yang berlainan. Dosis ke dua diberikan 1-2 bulan sesudahnya, dan dosis ke tiga diberikan pada usia 6 bulan.
3. Bayi lahir dari ibu dengan HBsAg negatif.

Diberikan vaksin rekombinan secara intramuskular pada umur 2-6 bulan. Dosis ke dua diberikan 1-2 bulan kemudian dan dosis ke tiga diberikan 6 bulan setelah imunisasi pertama.

Bayi prematur, termasuk bayi berat lahir rendah, tetap dianjurkan untuk diberikan imunisasi, ${ }^{6}$ sesuai dengan umur kronologisnya dengan dosis dan jadwal yang sama dengan bayi cukup bulan. ${ }^{5,8,9,13}$ Tabel 1 memperlihatkan pola pemberian imunisasi pada bayi prematur atau bayi berat lahir rendah. ${ }^{7}$

Pemberian vaksin HB pada bayi prematur dapat juga dilakukan dengan cara di bawah ini: ${ }^{13}$

1. Bayi prematur dengan ibu $\mathrm{HBsAg}$ positif harus diberikan imunisasi HB bersamaan dengan HBIG pada 2 tempat yang berlainan dalam waktu 12 jam. Dosis ke-2 diberikan 1 bulan kemudian, dosis ke3 dan ke-4 diberikan umur 6 dan 12 bulan.

2. Bayi prematur dengan ibu $\mathrm{HBsAg}$ negatif pemberian imunisasi dapat dengan :

a. Dosis pertama saat lahir, ke-2 diberikan pada umur 2 bulan, ke-3 dan ke-4 diberikan pada umur 6 dan 12 bulan. Titer anti Hbs diperiksa setelah imunisasi ke-4.

b. Dosis pertama diberikan saat bayi sudah mencapai berat badan 2000 gram atau sekitar umur 2 bulan. Vaksinasi HB pertama dapat diberikan bersama-sama DPT, OPV (IPV) dan Haemophylus influenzae B (Hib). Dosis ke-2 diberikan 1 bulan kemudian dan dosis ke-3 pada umur 8 bulan. Titer antibodi diperiksa setelah imunisasi ke-3.

American Academy of Pediatrics (AAP) menganjurkan pemberian imunisasi $\mathrm{HB}$ pada bayi prematur

Tabel 1. Pola pemberian imunisasi Hepatitis B pada bayi prematur dan bayi berat lahir rendah ${ }^{7}$

\begin{tabular}{|c|c|c|c|c|}
\hline Status ibu & Imunisasi & Saat pemberian & Dosis (ml) & Jadwal \\
\hline \multirow[t]{2}{*}{ Pengidap } & Aktif & $\begin{array}{l}12 \text { jam pertama } \\
\text { setelah lahir }\end{array}$ & $10 \mu \mathrm{g}(0,5)$ & $0,1,6$ bulan* \\
\hline & Pasif & 12 jam pertama & $0,5 \mathrm{ml} \mathrm{HBIG}$ & 1 kali \\
\hline Bukan pengidap & Aktif & $\begin{array}{l}\text { Berat } \geq 2,0 \mathrm{~kg} \text { atau } \\
\text { Usia } \geq 2 \text { bulan }\end{array}$ & $10 \mu \mathrm{g}(0,5)$ & $0,1,6$ bulan \\
\hline \multirow[t]{2}{*}{ Tidak diketahui } & $\begin{array}{l}\text { Aktif } \\
\text { Pasif }\end{array}$ & $\begin{array}{l}12 \text { jam pertama } \\
\text { Tidak perlu, }\end{array}$ & $10 \mu \mathrm{g}(0,5)$ & $0,1,6$ bulan* \\
\hline & & $\begin{array}{l}\text { kecuali }<7 \text { hari ternyata } \\
\text { diketahui ibu pengidap }\end{array}$ & 0,5 ml HBIG (100U) & 1 kali \\
\hline
\end{tabular}

Catatan

* Bulan ke-7 idealnya diperiksa anti HBs, bila hasilnya negatif, diberikan vaksin dosis ke-4. 
dengan cara sebagai berikut: ${ }^{14}$

1. Bayi yang lahir dari Ibu HBsAg negatif dan berat badan $<2 \mathrm{~kg}$; pemberian imunisasi ditunda sampai anak keluar dari rumah sakit, yaitu sampai berat badan anak $\geq 2 \mathrm{~kg}$ atau umur anak \pm 2 bulan. Vaksinasi yang diberikan sebanyak 3 dosis. Pada pasien ini tidak diperlukan pemeriksaan serologik.

2. Bayi yang lahir dari Ibu dengan HBsAg positif:

- Bayi prematur: dosis pertama diberikan dalam 12 jam pertama. Dosis kedua diberikan $1-2$ bulan kemudian dan dosis ketiga pada umur $6-18$ bulan. HBIG $0,5 \mathrm{ml}$ diberikan segera pada tempat yang berbeda.

- Bayi prematur dengan berat lahir < $2 \mathrm{~kg}$ : dosis pertama yang diberikan tidak dihitung, dilanjutkan 3 dosis lagi sampai total 4 dosis. Pemeriksaan anti-HBs dan HBsAg dilakukan 1-3 bulan setelah dosis ke empat. Bila konsentrasi anti $\mathrm{HBs}<10 \mathrm{mIU} / \mathrm{ml}$ berikan 3 dosis lagi dengan jadwal 0,1 dan 6 bulan diikuti pemeriksaan anti HBs 1 bulan sesudah dosis ke tiga.

3. Bayi yang lahir dari Ibu dengan status HBsAg tidak diketahui:

Bayi prematur dengan berat lahir $<2 \mathrm{~kg}$ : status HBsAg Ibu diperiksa sesegera mungkin, bila dalam 12 jam tidak dapat ditentukan maka berikan HBIG 0,5 ml dan vaksinasi dosis pertama. Bila ternyata $\mathrm{HBsAg}$ ibu positif, maka dosis pertama tidak dihitung, lanjutkan sebanyak 3 dosis lagi sampai total 4 dosis. Pemeriksaan anti-HBs dan HBsAg dilakukan 1-3 bulan setelah dosis ke empat. Bila konsentrasi anti $\mathrm{HBs}<10 \mathrm{mIU} / \mathrm{ml}$ diberikan 3 dosis lagi dengan jadwal 0,1 dan 6 bulan, diikuti dengan pemeriksaan anti $\mathrm{HBs} 1$ bulan sesudah dosis ke tiga.

Hal-hal yang perlu diperhatikan pada bayi kurang bulan adalah titer imunitas pasif melalui transmisi maternal lebih rendah daripada bayi cukup bulan, ${ }^{5,9}$ dan respons imun bayi-bayi tersebut masih belum efektif.' Sistem imun belum cukup matur untuk meningkatkan respon imun yang adekuat. ${ }^{15}$ Bila imunisasi diberikan segera setelah lahir, hanya 53-68 $\%$ yang akan mengalami serokonversi 1 bulan pasca imunisasi ke tiga. Penundaan imunisasi akan meningkatkan angka serokonversi menjadi $90 \%$, tetapi dengan lama proteksi yang belum diketahui. ${ }^{7}$ Keberhasilan imunisasi tergantung beberapa faktor, yaitu: status imun, faktor genetik pejamu, serta kualitas dan kuantitas vaksin. ${ }^{16}$ Keberhasilan imunisasi memerlukan maturitas imunologik. Pada neonatus, fungsi makrofag masih kurang, terutama fungsi mempresentasikan antigen karena ekspresi HLA (buman leukocyte antigen) pada permukaannya masih kurang dan deformabilitas membran serta respons kemotaktik yang masih kurang. Kadar komplemen dan aktivitas opsonin komplemen masih rendah demikian pula aktivitas kemotaktik serta daya lisisnya. Fungsi sel Ts (T supressor) relatif lebih menonjol dibandingkan pada bayi atau anak karena memang fungsi imun pada masa intra uterin lebih ditekankan pada toleransi. Hal ini masih terlihat pada bayi baru lahir. Pembentukan antibodi spesifik terhadap antigen tertentu masih kurang. Dengan sendirinya, vaksinasi pada neonatus akan memberikan hasil yang kurang sempurna dibandingkan dengan anak. ${ }^{16}$ Namun demikian bayi prematur atau bayi berat lahir rendah tetap dianjurkan untuk diimunisasi sesuai usia kronologisnya, dan dosis vaksin tidak perlu dikurangi. ${ }^{6,15,17-24}$

Waktu yang optimal bagi pemberian imunisasi HB pada bayi prematur dengan ibu HBsAg negatif belum dapat dipastikan. Beberapa laporan menyebutkan ditemuinya kadar serokonversi yang lebih rendah pada bayi berat lahir rendah yang diimunisasi segera setelah lahir dibandingkan dengan bayi prematur yang diimunisasi lebih lambat dan bayi cukup bulan yang diimunisasi segera setelah lahir. Oleh karena itu, dianjurkan untuk menunda imunisasi bayi prematur dengan berat lahir kurang dari $2 \mathrm{~kg}$ dengan ibu HBsAg negatif sampai mereka meninggalkan rumah sakit, yaitu pada waktu berat bayi mencapai $2 \mathrm{~kg}$ atau lebih ${ }^{14,25}$ atau setidaknya sampai umur 2 bulan, diberikan bersamaan dengan imunisasi lain. ${ }^{6,14,23,24}$ Apabila imunisasi HB diberikan sebelum bayi berumur 2 bulan, dianjurkan memberikan imunisasi ulangan. ${ }^{17}$

Bayi prematur atau bayi berat lahir rendah dari ibu pengidap HVB, seyogyanya imunisasi dan HBIG diberikan segera setelah lahir, ${ }^{7}$ serta dilakukan pemeriksaan anti $\mathrm{HBs}$ satu bulan sesudah imunisasi ke tiga ${ }^{5,7,11}$ atau ke empat. ${ }^{14}$ Penelitian kohort multisenter di Thailand dan Taiwan terhadap bayi dari ibu pengidap HB yang telah memperoleh imunisasi dasar 3x pada masa bayi, didapatkan bahwa pada umur 5 tahun, 90,7 \% di antaranya masih memiliki titer antibodi anti $\mathrm{HBs}$ yang protektif ( titer anti $\mathrm{HBs}>10$ $\mathrm{mlU} / \mathrm{ml}$ ). Mengingat pola epidemiologi $\mathrm{HB}$ di Indonesia mirip dengan negara tersebut, maka dapat disimpulkan bahwa imunisasi ulang pada usia 5 tahun 
tidak diperlukan kecuali apabila titer anti $\mathrm{HBsAg}<10$ $\mathrm{mlU} / \mathrm{ml} .^{5,11}$ Bila status ibu tidak diketahui sebaiknya diberikan sesuai imunisasi pada bayi dengan ibu HBsAg positif. ${ }^{13}$ Apabila sampai dengan usia 5 tahun anak belum pernah memperoleh imunisasi HB, maka secepatnya diberikan (catch-up vaccination). Ulangan imunisasi HB (hep B-4) dapat dipertimbangkan pada umur 10-12 tahun. ${ }^{5,11}$

Saat ini telah beredar vaksin kombinasi $\mathrm{HB}$ dengan DPT. Untuk bayi berumur $<6$ minggu pemberian vaksin kombinasi ini tidak dianjurkan karena DPT hanya diberikan pada umur $>2$ bulan jadi tidak dapat diberikan sebagai imunisasi HB pertama pada bayi baru lahir. ${ }^{13}$

\section{Hal-hal yang perlu diperhatikan}

Penyuntikan dianjurkan di daerah deltoid atau paha anterolateral. ${ }^{2,7,27}$ Titer antibodi pada penyuntikan di deltoid, terbukti 17 kali lebih tinggi dibandingkan dengan penyuntikan di regio gluteus. Kurang lebih $20 \%$ subyek dengan suntikan di gluteus gagal memproduksi antibodi protektif, hal ini mungkin disebabkan karena banyaknya jaringan lemak sehingga suntikan tidak mencapai otot. ${ }^{2,7}$ Efektifitas vaksin $\mathrm{HB}$ berkisar antara 90-95\% (pada titer anti HBs > 10 $\mathrm{mlU} / \mathrm{ml}$ ). Memori sistem imun diperkirakan menetap paling tidak sampai dengan 12 tahun pasca imunisasi. Dalam keadaan normal, tidak dianjurkan untuk memberikan imunisasi ulangan (booster). ${ }^{7}$ Pada bayi dan anak, tidak dianjurkan untuk melakukan pemeriksaan anti $\mathrm{HBs}$ pra dan pasca imunisasi secara rutin. Uji serologi pasca imunisasi hanya dilakukan pada populasi risiko tinggi, yaitu 1-2 bulan sesudah imunisasi yang ketiga. ${ }^{7}$

\section{Kesimpulan}

1. Pada dasarnya jadwal imunisasi hepatitis B bayi kurang bulan atau bayi berat lahir rendah sama dengan bayi cukup bulan, hanya dosis yang pertama diberikan pada umur 2 bulan atau lebih sesuai dengan usia kronologisnya, atau berat badan telah mencapai $\geq 2 \mathrm{~kg}$. Kecuali apabila diketahui ibu mempunyai titer $\mathrm{HBs} A g$ positif, imunisasi $\mathrm{HB}$ mulai diberikan dalam 12 jam pertama dan dosis pertama ini tidak dihitung, namun dilanjutkan 3 dosis lagi sampai total 4 dosis dengan jadwal yang sama dengan bayi cukup bulan ( $0,1,6$ bulan).

2. Hal-hal yang perlu diperhatikan pada pemberian imunisasi $\mathrm{HB}$ :

a. Pada bayi kurang bulan atau bayi berat lahir rendah titer imunitas pasif melalui transmisi maternal lebih rendah daripada bayi cukup bulan.

b. Penyuntikan dianjurkan di daerah deltoid atau paha anterolateral.

c. Imunisasi ulangan secara rutin pada usia di bawah 12 tahun tidak dianjurkan. Memori sistem imun diperkirakan menetap paling tidak sampai dengan 12 tahun pasca imunisasi.

\section{Daftar Pustaka}

1. Hadinegoro SRH. Pedoman pelaksanaan imunisasi pada anak. Dalam: Tumbelaka AR, Hadinegoro SRH, Satari HI, Oswari H, penyunting. Strategi pemilihan dan penggunaan vaksin serta antibiotik dalam upaya antisipasi era perubahan pola penyakit. Naskah lengkap Pendidikan Kedokteran Berkelanjutan Ilmu Kesehatan Anak FKUI XXXIX. FKUI; 1997. Jakarta: Balai Penerbit FKUI 1997. h. 49-37.

2. Lubis I.Z. Vaksinasi HB pada bayi dan anak. Majalah Kedokteran Nusantara 1990; 3:157-64.

3. Soemara LH. Vaksinasi hepatitis B. Dalam: Zulkarnain $\mathrm{Z}$, Bisanto J, Pujiarto PS, Oswari $\mathrm{H}$, penyunting. Tinjauan komprehensif hepatitis virus pada anak, Naskah Lengkap Pendidikan Kedokteran Berkelanjutan Ilmu Kesehatan Anak XLlll. FKUI; 2000; Jakarta: Balai Penerbit FKUI, 2000. h. 106-99.

4. Peter G. Immunization practices. Dalam: Behrman RE, Kliegman RM, Jenson HB, penyunting. Nelson Textbook of Pediatrics. Edisi ke-16. Philadelphia: Saunders, 2000. h. 1081-9.

5. Satgas Imunisasi IDAI. Jadwal imunisasi rekomendasi IDAI. Sari Pediatri 2000; 2:43-7.

6. Satari HI. Imunisasi pada keadaan khusus. Dalam: Tumbelaka AR, Hadinegoro SRH, Satari HI, Oswari $\mathrm{H}$, penyunting. Strategi pemilihan dan penggunaan vaksin serta antibiotik dalam upaya antisipasi era perubahan pola penyakit. Naskah lengkap Pendidikan Kedokteran Berkelanjutan Ilmu Kesehatan Anak FKUI XXXIX. FKUI; 1997; Jakarta: Balai Penerbit FKUI, 1997. h. 63-51.

7. Pujiarto PS. Kebijakan tatalaksana hepatitis virus A,B,C, pada anak. Dalam: Zulkarnain Z, Bisanto J, Pujiarto PS, Oswari H, penyunting. Tinjauan komprehensif hepatitis virus pada anak. Naskah lengkap Pendidikan Kedokteran Berkelanjutan Ilmu Kesehatan Anak FKUI XLlll. FKUI; 2000;Jakarta: Balai Penerit FKUI 2000. h. 136-113.

8. Hadinegoro SRS. Kejadian ikutan pasca imunisasi. Sari Pediatri, 2000; 2:2-10. 
9. Tim Satuan Tugas Imunisasi PP IDAI. Jadwal imunisasi PP IDAI edisi Agustus 1999. Buku prosiding Kongres Nasional Ilmu Kesehatan Anak XI, Jakarta, Juli 4-7, 1999.

10. American Academy of Pediarics, Committee on Infectious Diseases. Recommended childhood immunization schedule-United States, January-December 1997. Pediatrics 1997; 99:136-7.

11. Hadinegoro SRS. Jadwal imunisasi rekomendasi IDAI. Dalam: Ranuh I.G.N, Soeyitno H, Hadinegoro SRS, Kartasasmita C, penyunting. Buku Imunisasi di Indonesia, edisi pertama. 2001. Jakarta: Satgas Imunisasi IDAI, 2001. h. 63-9.

12. Direktorat Jenderal PPM dan PLP, Departemen Kesehatan Republik Indonesia. Petunjuk teknis pelaksanaan imunisasi hepatitis B. Edisi ke-4. Jakarta:1997.

13. Siregar SP. Imunisasi pada kelompok berisiko. Dalam: Ranuh IGN, Soeyitno H, Hadinegoro SRS, Kartasasmita $\mathrm{C}$, penyunting. Buku Imunisasi Di Indonesia, edisi pertama. 2001. Jakara: Satgas Imunisasi -IDAI, 2001. h. 49-56.

14. American Academy of Pediatrics. Hepatitis A, B, C and E. Dalam: Peter G, Hall CB, Halsey NA, Marcey SM, Pickering LK, penyunting. 1997 Red Book. Report of the committee on infectious diseases, edisi ke-24, 1997. h. 254-9.

15. American Academy of Pediatrics. Routine immunization of preterm infants. Lancet, 1990; 335:23-4.

16. Matondang CS. Aspek imunologi imunisasi. Dalam: Ranuh IGN, Soeyitno H, Hadinegoro SRS, Kartasasmita $\mathrm{C}$, penyunting. Buku Imunisasi di Indonesia, edisi pertama. 2001. Jakarta Satgas Imunisasi-IDAI, 2001. h. 5-11.
17. Khalak R, Pichichero ME, D'Angio CT. Three - year follow up of vaccine response in extremely preterm infants. Pediatrics 1998; 101:597-603.

18. Pullan CR, Hull D. Routine immunization of preterm infants. Arch Dis Child 1989; 64:1438-41.

19. Chirico G, Belloni C, Gasparoni A. Hepatitis B immunization in infants of $\mathrm{HB}$ surface antigen negative mothers [Experience and reason]. Pediatrics 1993; 717-9.

20. Hall CB, Halsey NA. Control of hepatitis B. to be or not to be?[Commentaries]. Pediatrics 1992; 274-7.

21. Lau Y, Tam AYC, Ng KW. Response of preterm infants to $\mathrm{HB}$ vaccine. J Pediatr 1992; 121:962-5.

22. Del Canho R, Grosheide PM, Gerards LJ, Heijtink RA, Schalm SW. Hepatitis B vaccination and preterm infants. Pediatr Infect Dis J 1993; 12: 407-8.

23. Americana Academy of Pediatrics, Committee on infectious Diseases. Up date on timing of $\mathrm{HB}$ vaccination for premature infants and for children with lapsed immunization. Pediatrics 1994; 94:403-4.

24. Atkinson W, Humiston S, Wolfe C, Nelson R. Epidemiology and prevention of vaccine-preventable diseases. Edisi ke-2. Atlanta: Department of Health \& Human Services, 1999. h. 232-8.

25. Patel DM, Butler J, Feldman S, Graves GR, Rhodes PG. Immunogenicity of $\mathrm{HB}$ vaccine in healthy very low birth weight infants. J Pediatr 1997; 130:641-3.

26. Pujiarto PS, Zulkarnain Z, Bisanto J, Oswari H. Bayi terlahir dari ibu pengidap hepatitis B. Sari Pediatri, 2000; 2:48-9.

27. American Academy of Pediatrics, Committee on Infectious Disease. Universal HB immunization. Pediatrics 1992; 89:795-800. 